\title{
Dibenzoyl-methane Derivatives as a Potential and Exciting New Therapy for the Treatment of Childhood Bone Cancer
}

\author{
EMAN ALMELAH ${ }^{1}$, DAVID P. T. SMITH ${ }^{1}$, ANDREW MCGOWN $^{1}$, \\ ATHAR AZIZ ${ }^{1}$, HERMAN J POTGIETER ${ }^{2}$ and PATRICIA RAGAZZON ${ }^{1}$ \\ ${ }^{1}$ School of Environment and Life Sciences, College of Science and Technology University of Salford, Manchester, U.K.; \\ ${ }^{2}$ Division of Chemistry \& Environmental, Science Manchester Metropolitan University, Manchester, U.K.
}

\begin{abstract}
Childhood bone cancer though rare, has very limited treatment choices, with poor survival rates and often involving amputation. We developed a novel molecule, 2', 4'dihydroxy-dithion-dibenzoyl-methane and tested it on hepatic, colon, lung and osteoblast cancer cell lines. Thionylation of 2', 4'- dihydroxydibenzoylmethane led to selective targeting of bone cancer cells, stopping their growth and leading to their death without affecting non-cancerous cells within the bone marrow or other non-malignant cells.
\end{abstract}

Cancer in bones can be either primary (initiated in the bones) or secondary (has spread to the bones) in nature. In primary bone cancer, osteosarcoma can affect any bone in the skeleton, though the femur, tibia and humerus are most commonly affected. Osteosarcoma accounts for about 3\% of cancers in children, especially during early adolescence when bone growth is at its peak (1). Ewing's sarcoma affects mainly teenagers and has an incidence of $34 \%$ among all bone cancers. It appears mainly in the pelvis, thigh and shin areas, although this type of tumour can also occur in soft tissues (soft-tissue sarcoma) (2). Rare forms of bone cancer account for the remaining $6 \%$ of bone cancer in children (3). Other primary bone cancers that affect mainly adults over 40 years old, are chondrosarcoma in hips, legs, arms and shoulders; several variations of spindle-cell sarcoma; and chordoma in lungs, nearby bones, lymph nodes, liver and skin. Secondary cancers can arise from primary tumours spreading to other tissues and the most prevalent tumours resulting from secondary bone cancers are those of the prostate, breast, lung, kidney and thyroid.

Survival rate after treatment depends highly on the patient's age at the time of diagnosis, and the stage and type of bone cancer. In teenagers with Ewing's sarcoma, survival

Correspondence to: Patricia Ragazzon, Room G02, Cockcroft Building, School of Environment and Life Sciences, University of Salford, Manchester, M54WT, U.K. E-mail: p.a.ragazzon@salford.ac.uk

Key Words: Bone cancer, dibenzoylmethane, childhood. rate after treatment ranges from $20-70 \%$ over 5 years, but is dependent on the site and size of the tumour (4-7). Treatment generally involves some type of surgery, and the stage of cancer will determine which type of surgery will be used. It can vary from removing only the area affected in the bone to amputation of the limb. Further treatment can include radiotherapy and chemotherapy (8-10). Osteosarcomas can be treated with doxorubicin (a DNA intercalator), methotrexate (an antimetabolite) and cisplatin (a DNA alkylator). Ewing's sarcoma requires a mixture of drugs, including cocktail 1 consisting of vincristine (antimitotic agent), ifosfamide (DNA alkylator), doxorubicin, and etoposide (topoisomerase II inhibitor). This is followed by cocktail 2 made up of vincristine, ifosfamide and actinomycin D (DNA groove binder) with/without cocktail 3 , which is a mixture of vincristine, actinomycin D and cyclophosphamide (DNA alkylator). Treatment of bone cancer with small molecules can be effective depending on the type of cancer and stage. However, there are side-effects which affect the outcome for the patient. This can affect the rate of remission, produce delays in recovery times or cause long-term effects such as fertility problems (11-16). Biological therapies are currently being evaluated in clinical trials, with the aim of identifying new molecules (generally antibodies or adjuvants) which encourage the immune system to attack the cancer cells by recruiting immune-modulators such as tumour necrosis factors (TNFs) and interferons.

Dibenzoyl-methane derivatives (DBMD) (Figure 1) have been found in green tea leaves from Camellia sinensis and have been used in traditional medicine to treat several conditions, ranging from infection to rheumatic diseases, and as antioxidants. Their biological activity has not been completely elucidated, but studies in other cell lines indicate activities in p53, retinoblastoma, and mitochondria (17-20).

Generation of DBMD derivatives. We employed the improved Baker-Venkatarman arrangement (21), (Figure 2) to produce five dibenzoyl-methane derivatives: 2',4'-dihydroxy-dibenzoylmethane (1), 2'-hydroxy-4'amino-dibenzoyl-methane (2), 
2',4'-dihydroxy3'"methoxy-dibenzoyl-methane (3), and 2',4'dihydroxy4"methoxy-dibenzoyl-methane (4). Thionylation of 2',4'-dihydroxy-dibenzoyl-methane produced 2',4'-dihydroxydithiodibenzoyl-methane (DBM-S, 5) (Figure 3).

This article describes the development a novel molecule, 2', 4'dihydroxy-dithiondibenzoyl-methane and derivatives thereof and highly promising results obtained for cell viability in applying it against hepatic, colon, lung and osteoblasts cancer cell lines with subsequent in-depth studies in osteoblasts.

\section{Materials and Methods}

Materials. A combination of compounds were obtained from various suppliers. Alfa Aesar, Heysham, Lancashire UK: 3', 4', 5'Trimethoxyacetophenone, benzoyl chloride, 3-methoxybenzoyl chloride, Lawesson's reagent. TCI Tokyio Kasei, Birkenhead UK:2', 4' Dihydroxyacetophenone, 4-Methoxybenzoyl chloride. Fluorochem, Hadfield, Derbyshire, UK: Potassium tert-butoxide and silica gel (60 ̊). Thermo Fisher Scientific, Altrincham, Greater Manchester, UK: 4-Amino-2-hydroxyacetophenone, anhydrous tetrahydrofuran (THF), hydrochloric acid, toluene, ethyl acetate, petroleum ether, ethanol, hexane, dimethylsulfoxide (DMSO), foetal bovine serum (GIBCO), RPMI-1640 (Roswell Park Memorial Institute Medium) (HyClone), 0.05\% Trypsin-EDTA (GIBCO), sterile phosphate-buffered saline (sPBS), tetramethylsilane (TMS). VWR West Sussex, UK: TLC (Thin layer chromatography) silica gel 60 F245 (Merck). Cambridge Isotope Laboratories, Tewksbury, MA, USA: Deuterated chloroform $\left(\mathrm{CDCl}_{3}\right)$. Sigma-Aldrich, Dorset UK: L-Glutamine 100x, Minimal Essential Media (MEM) nonessential amino acid $100 x$, penicillin-streptomycin $100 x$, chlorpromazine hydrochloride, 3(4,5-dimethylthiazol-2-yl)2,5diphenyl-tetrazolium bromide (MTT) and Saos2 cell line. University of Salford Cell Bank, Salford, Greater Manchester UK: HCT116 and A549 cell lines. Cyprotex, Macclesfield, East Cheshire UK: HepG2 cell line. Eurofin, Manchester, Manchester UK: oligonucleotides. Accurate mass spectrometry was performed in a liquid chromatography mass spectrometer (LCMS) Agilent 6540 accurate mass quadruple time-of-flight, (Yanton, Oxford, UK). Infra-red (IR) analysis was performed in a Nicolet ${ }^{\mathrm{TM}} \mathrm{Is}^{\mathrm{TM}} 50$ FT-IR attenuated total reflectance (ATR) (Thermo Fisher Scientific, Altrincham, Greater Manchester, UK). ${ }^{1} \mathrm{H}$ (proton) and ${ }^{13} \mathrm{C}$ (carbon) nuclear magnetic resonance (NMR) was performed in a Bruker TOPSPIN $400 \mathrm{MHz}$ (Coventry, UK) using TMS as control.

Synthesis. 2',4'-Dihydroxy-dibenzoyl-methane (1): Under argon, 1(4amino-2-hydroxy-phenyl)-ethanone $(6.57 \mathrm{mmol}, 1.0 \mathrm{~g})$ dissolved in anhydrous THF $(20 \mathrm{ml})$ was added dropwise to a cooled $\left(0^{\circ} \mathrm{C}\right)$ solution of KOtBu (10.51 mmol, $1.18 \mathrm{~g})$ in anhydrous THF $(50 \mathrm{ml})$. The solution was then stirred at room temperature for $1 \mathrm{~h}$, then chilled to $0^{\circ} \mathrm{C}$ before benzoyl chloride $(6.57 \mathrm{mmol}, 0.762 \mathrm{ml})$ was added dropwise and stirred at room temperature for $1 \mathrm{~h}$, before being cooled $\left(0^{\circ} \mathrm{C}\right)$, to which $\mathrm{KO}^{\text {t } B u}(10.51 \mathrm{mmol}, 1.18 \mathrm{~g})$ was added and then stirred at room temperature for $15 \mathrm{~min}$, followed by $24 \mathrm{~h}$ under reflux. The product was extracted by the addition of $0.5 \mathrm{M} \mathrm{HCl}(100 \mathrm{ml})$ producing a light yellow precipitate, which was then recrystallized with ethanol to yield yellow needles. Yield: $51.2 \%$. Yellow solid. Melting point: $158-161^{\circ} \mathrm{C} .{ }^{1} \mathrm{H} \mathrm{NMR}\left(\mathrm{CDCl}_{3}\right.$, TMS, $300 \mathrm{MHz}): \delta=3.4(\mathrm{~s}, 1 \mathrm{H}), 4.6(\mathrm{~s}, 1 \mathrm{H}), 6.8(\mathrm{~s}, 1 \mathrm{H}), 6.9-8.3(\mathrm{~m}$,

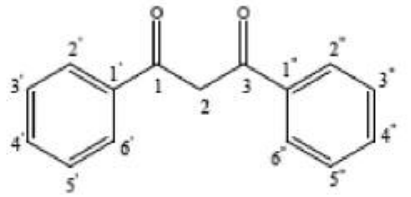

Figure 1. Dibenzoyl-methane.

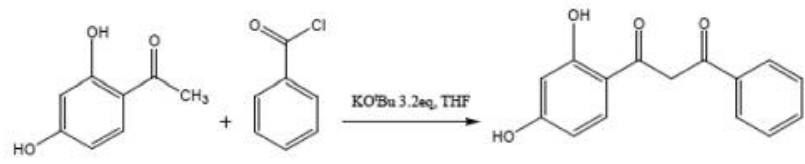

Figure 2. Scaffold formation by reacting different analogues of 2-hydroxyacetophenone with benzoyl chloride and addition of potassium tert-butoxide.

8H), $11.7(\mathrm{~s}, 1 \mathrm{H}), 12.4(\mathrm{~s}, 1 \mathrm{H}), 15.5(\mathrm{~s}, 1 \mathrm{H}),{ }^{13} \mathrm{C} \mathrm{NMR}\left(\mathrm{CDCl}_{3}\right.$, TMS, $300 \mathrm{MHz}): \delta=63.22,98.73,101.3,102.79,121.18,121.42$, 123.66, 125.56, 125.84, 126.87, 127.58, 158.05, 159.74, 197.66, 189.22. FT-IR (ATR) $\left(\mathrm{cm}^{-1}\right)$ : 3060, 1741, 1621, 1588, 1497, 1452, 1430, 1298, 1236, 1205. LC-MS m/z: 255.0654(M-H) $)^{-1}$.

2'Hydroxy,4'aminodibenzoylmethane (2): Under argon, 2hydroxy-4-amino-dibenzoyl-methane (1.32 mmol, $0.2 \mathrm{~g})$ dissolved in anhydrous THF $(8 \mathrm{ml})$ was added dropwise to a cooled mixture $\left(0^{\circ} \mathrm{C}\right)$ of $\mathrm{KO}^{\mathrm{t}} \mathrm{Bu}(2.11 \mathrm{mmol}, 0.24 \mathrm{~g})$ in anhydrous THF $(15 \mathrm{ml})$. The solution was then stirred at room temperature for $1 \mathrm{~h}$. The reaction was then re-cooled $\left(0^{\circ} \mathrm{C}\right)$ to which benzoyl chloride $(1.32 \mathrm{mmol}$, $0.154 \mathrm{ml}$ ) was added dropwise, and then stirred at room temperature for further $1 \mathrm{~h}$. The reaction was cooled to $\left(0^{\circ} \mathrm{C}\right)$ before $\mathrm{KOtBu}$ $(2.11 \mathrm{mmol}, 0.24 \mathrm{~g})$ was added and the mixture stirred at room temperature for $15 \mathrm{~min}$, followed by reflux for $24 \mathrm{~h}$. The product was extracted by the addition of $0.5 \mathrm{M} \mathrm{HCl}(100 \mathrm{ml})$, producing a brown yellow precipitate, which was then recrystallized with ethanol to yield yellow needles and purified by flash chromatography [silica, petroleum ether (40-60): ethyl acetate]. Yield: $46.3 \%$. Yellow solid. Melting point: $110-112^{\circ} \mathrm{C} .{ }^{1} \mathrm{H}$ NMR $\left(\mathrm{CDCl}_{3}, \mathrm{TMS}, 300 \mathrm{MHz}\right): \delta=4.6(\mathrm{~s}, 1 \mathrm{H}), 5.3(\mathrm{~s}, 2 \mathrm{H}), 6.8(\mathrm{~s}, 1 \mathrm{H})$, 6.9-8.2 (m, 8H), $11.8(\mathrm{~s}, 1 \mathrm{H}), 12.4(\mathrm{~s}, 1 \mathrm{H}), 15.5(\mathrm{~s}, 1 \mathrm{H}) .{ }^{13} \mathrm{C} \mathrm{NMR}$ $\left(\mathrm{CDCl}_{3}, \mathrm{TMS}, 300 \mathrm{MHz}\right): \delta=26.41,92.13,108.14,115.44,127.14$, $128.50,129.92,132.13,133.68,134.38,144.66,163.83,163.88$, 176.87, 194.45. FT-IR (ATR) $\left(\mathrm{cm}^{-1}\right) 3496,3370,1671,1602,1572$, $1508,1488,1456,1358,1270,1218,1191,1151,1043$. LC-MS m/z: $254.0818(\mathrm{M}-\mathrm{H})^{-1}$.

2',4'-Dihydroxy-3"'-methoxy-dibenzoyl-methane (3): Under argon, 2',4'-dihydroxy-acetophenone (6.57 $\mathrm{mmol}, 1.0 \mathrm{~g})$ was dissolved in anhydrous THF $(20 \mathrm{ml})$ and then added dropwise to a cooled solution $\left(0^{\circ} \mathrm{C}\right)$ of $\mathrm{KO}^{\mathrm{t}} \mathrm{Bu}(10.51 \mathrm{mmol}, 1.18 \mathrm{~g})$ in anhydrous THF $(50 \mathrm{ml})$, followed by stirring at room temperature for $1 \mathrm{~h}$. The reaction was then cooled $\left(0^{\circ} \mathrm{C}\right)$ before 3-methoxybenzoyl chloride $(6.57 \mathrm{mmol}, 0.923 \mathrm{ml})$ was added dropwise and then stirred at room temperature for a further $1 \mathrm{~h}$. The mixture was cooled $\left(0^{\circ} \mathrm{C}\right)$ before $\mathrm{KO}^{\mathrm{t}} \mathrm{Bu}(10.51 \mathrm{mmol}, 1.18 \mathrm{~g})$ was added and then stirred at room temperature for $15 \mathrm{~min}$, then refluxed for 24 hours. The product was extracted by the addition of $0.5 \mathrm{M} \mathrm{HCl}(100 \mathrm{ml})$, producing a light yellow precipitate, then recrystallized with ethanol to yield yellow 


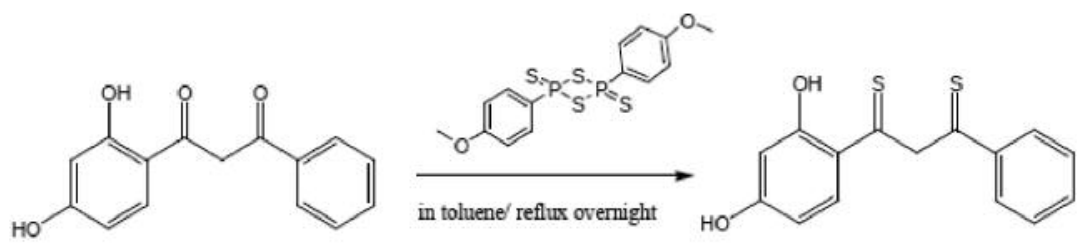

Figure 3. Thionylation of 2',4'dihydroxy-dibenzoyl-methane using Lawesson's reagent.

needles and purified by flash chromatography [silica, petroleum ether (40-60): ethyl acetate]. Yield: 47.1\%. Yellow solid. Melting point: $110-112^{\circ} \mathrm{C} .{ }^{1} \mathrm{H} \mathrm{NMR}\left(\mathrm{CDCl}_{3}, \mathrm{TMS}, 300 \mathrm{MHz}\right): \delta=3.5(\mathrm{~s}, 1 \mathrm{H})$, б $3.9(\mathrm{~s}, 3 \mathrm{H}), 4.6(\mathrm{~s}, 1 \mathrm{H}), 6.8(\mathrm{~s}, 1 \mathrm{H}), 6.9-8(\mathrm{~m}, 7 \mathrm{H}), 11.8(\mathrm{~s}, 1 \mathrm{H})$, $12.4(\mathrm{~s}, 1 \mathrm{H}), 15.5(\mathrm{~s}, 1 \mathrm{H}),{ }^{13} \mathrm{C}$ NMR $\left(\mathrm{CDCl}_{3}, \mathrm{TMS}, 300 \mathrm{MHz}\right)$ : $\delta=55.53,92.50,113.15,114.55,119.21,120.51,129.75,130.24$ 134.92, 163.96, 164.22, 177.36, 194.72. FTIR (ATR) (cm-1) 2834, $1741,1612,1583,1504,1489,1451,1320,1282,1042$, LC-MS $\mathrm{m} / z$ : $285.0763(\mathrm{M}-\mathrm{H})^{-1}$.

2',4'-Dihydroxy-4"'-methoxy-dibenzoyl-methane (4): Under argon, 2',4'-dihydroxy-acetophenone $(6.57 \mathrm{mmol}, 1.0 \mathrm{~g})$ was dissolved in anhydrous THF $(20 \mathrm{ml})$ was added dropwise to a cooled solution $\left(0^{\circ} \mathrm{C}\right)$ of $\mathrm{KOtBu}(10.51 \mathrm{mmol}, 1.18 \mathrm{~g})$ in anhydrous THF $(50 \mathrm{ml})$, followed by $1 \mathrm{~h}$ of stirring at room temperature. The solution was cooled to $0^{\circ} \mathrm{C}$ before 4-metoxybenzoyl chloride $(6.57 \mathrm{mmol}, 0.89 \mathrm{ml})$ was added dropwise, and then stirred at room temperature for a further $1 \mathrm{~h}$. The reaction was cooled again $\left(0^{\circ} \mathrm{C}\right)$ before adding KOtBu $(10.51 \mathrm{mmol}, 1.18 \mathrm{~g})$ followed by reflux for $24 \mathrm{~h}$. The product was extracted by the addition of $0.5 \mathrm{M} \mathrm{HCl}$ $(100 \mathrm{ml})$; a light yellow precipitate was formed, then recrystallized with ethanol to yield yellow needles and purified by flash chromatography [silica, petroleum ether (40-60): ethyl acetate]. Yield: $51.3 \%$. Yellow solid. Melting point: $137-141^{\circ} \mathrm{C} .{ }^{1} \mathrm{H}$ NMR $\left(\mathrm{CDCl}_{3}\right.$, TMS, 300MHz): $\delta=4.6(\mathrm{~s}, 1 \mathrm{H}), 6.75(\mathrm{~s}, 1 \mathrm{H}), 3.5(\mathrm{~s}, 1 \mathrm{H})$, $3.9(\mathrm{~s}, 3 \mathrm{H}) 6.8-8.3(\mathrm{~m}, 7 \mathrm{H}), 11.8(\mathrm{~s}, 1 \mathrm{H}), 12.4(\mathrm{~s}, 1 \mathrm{H}), 15.5(\mathrm{~s}, 1 \mathrm{H})$. ${ }^{13} \mathrm{C}$ NMR $\left(\mathrm{CDCl}_{3}, \mathrm{TMS}, 300 \mathrm{MHz}\right): \delta=26.33,55.40,102.24$, $108.07,112.82,113.77,122.91,131.30,133.69,164.16,166.96$, 202.68. FT-IR (ATR) $\left(\mathrm{cm}^{-1}\right) 3475,1727,1606,1509,1257,1241$, 1185, 1044, 1026. LC-MS m/z: $285.0764(\mathrm{M}-\mathrm{H})^{-1}$.

1(-2',4'-Dihydroxy-phenyl)-3-phenylpropane-1,3-dithion (5): Lawesson's reagent $(1.17 \mathrm{mmol})$ was added to $\left(2^{\prime}, 4\right.$ 'dihydroxy benzoyl)-methane $(1.95 \mathrm{mmol}, 0.5 \mathrm{~g})$ dissolved in toluene $(25 \mathrm{ml})$. The reaction was then refluxed for 24 hours. The solvent was removed using reduced pressure and the crude product was purified by preparative TLC (petroleum ether: ethyl acetate). Yield: $60.7 \%$. Red solid. Melting point: $165-167^{\circ} \mathrm{C} .{ }^{1} \mathrm{H}$ NMR $\left(\mathrm{CDCl}_{3}\right.$, TMS, $300 \mathrm{MHz}): \delta=3.3(\mathrm{~s}, 1 \mathrm{H}), 5.3(\mathrm{~s}, 2 \mathrm{H}), 6.9-8.5(\mathrm{~m}, 8 \mathrm{H}) .{ }^{13} \mathrm{C} \mathrm{NMR}$ $\left(\mathrm{CDCl}_{3}, \mathrm{TMS}, 300 \mathrm{MHz}\right): \delta=63.22,98.73,101.3,102.79,121.18$, $121.42,123.66,125.56,125.84,126.87,127.58,158.05,159.74$, 189.22, 197.66. FT-IR (ATR) $\left(\mathrm{cm}^{-1}\right) 2926,2369,1646,1597,1576$, $1448,1378,1223,1118$. LC-MS $m / z: 575.0751(2 \mathrm{M}-\mathrm{H})^{-1}$.

Cell culture. Cells (HepG2, A549, HCT116 and Saos2) were grown as an adherent monolayer culture in $75 \mathrm{~cm}^{2}$ flasks in RPMI- 1640 medium supplemented with $10 \%$ heat inactivated foetal bovine serum (FBS), $1 \% \mathrm{v} / \mathrm{v}$ nonessential amino acids, $2 \mathrm{mM} \mathrm{L}$-glutamine and 115 units $/ \mathrm{ml}$ of penicillin $\mathrm{G}$, and $115 \mu \mathrm{g} / \mathrm{ml}$ of streptomycin at $37^{\circ} \mathrm{C}$ under a humidified atmosphere containing $5 \% \mathrm{CO}_{2}$ and $95 \%$ air.
MTT assay. The five compounds were tested at a range of concentrations (range $=0-100 \mu \mathrm{M}$ ) and cell death percentage was determined by the colorimetric MTT micro-culture assay. Cells were detached from the $75 \mathrm{~cm} 2$ flasks (at a confluence of $70 \%$ ) by trypsinization, and seeded in $100 \mu \mathrm{l}$ aliquots into 96-well clear micro-culture plates. Cells (HepG2, A549, HCT116 and Saos2) at density of $3.0 \times 10^{3}$ cells/well were incubated for 72 hours in order to ensure exponential growth of untreated controls throughout the experiment. Cells were allowed to adhere to the 96-well microculture plate for $24 \mathrm{~h}$ prior to dosing. Stock solutions of the test compounds in DMSO were appropriately diluted in complete culture medium to make up the required concentrations, and then added in $25 \mu \mathrm{l}$ aliquots to the 96-well micro-culture plate. Cells were exposed to the test compounds for $72 \mathrm{~h}$. Plates were maintained at $37^{\circ} \mathrm{C}$ in a humidified atmosphere containing $95 \%$ air and $5 \% \mathrm{CO}_{2}$. At the end of the incubation period, $30 \mu \mathrm{l} / \mathrm{well}$ MTT solution in sPBS (3 mg/ $\mathrm{ml}$ ) were added, and then plates incubated for a further $3 \mathrm{~h}$. After the end of the incubation, the supernatants containing the medium and MTT were removed and the formazan crystals formed by viable cells were dissolved in $100 \mu \mathrm{l}$ of DMSO per well. Optical densities at $\lambda=540 \mathrm{~nm}$ were measured with LUMIistar Omega multi-mode plate reader (Edinburgh, UK). The colorimetric MTT assay was used to determine the cell death percentage at serial diluted concentrations of the tested compounds and the concentration at which $50 \%$ of cell growth was inhibited $\left(\mathrm{IC}_{50}\right)$ as compared to the control wells which did not contain any drug was determined from a dose-response curve using OriginPro 9.1 (Northampton, MA, USA) data analysis and graphing software. Chlorpromazine was used as positive control in the MTT assay. Data were collected as duplicates and statistical analysis calculated as standard deviation (SD) using Excel Microsoft (Reading, Berkshire, UK).

Caspase assay. 2', 4'-Dihydroxydithiondibenzoylmethane was tested at a range of concentrations (range $=0-5-10$ and $20 \mu \mathrm{M}$ ) and caspase activity was determined by using an ApotoxGlo ${ }^{\circledR}$ (Promega. Madison, WI, USA) assay. Cells (HepG2, A549, HCT116 and Saos2) were detached from the $75 \mathrm{~cm}^{2}$ flasks (at a confluence of 70\%) by trypsinization, and seeded in $100 \mu \mathrm{l}$ aliquots into 96-well clear microculture plates. Cells were allowed to adhere to the 96-well microculture plate for $24 \mathrm{~h}$ prior to dosing. Stock solutions of the test compounds in DMSO were appropriately diluted in complete culture medium to make up the required concentrations, and then added in 25 $\mu \mathrm{l}$ aliquots to the 96-well micro-culture plates. Cells were then incubated for 24,48 and $72 \mathrm{~h}$ at densities of 5,4 and $3.0 \times 10^{3}$ cells/wells, respectively. Plates were maintained at $37^{\circ} \mathrm{C}$ in a humidified atmosphere containing 95\% air and $5 \% \mathrm{CO}_{2}$. At the end of the incubation period, $20 \mu \mathrm{l} /$ well of the part 1 ApotoxGlo ${ }^{\circledR}$ was added and after $30 \mathrm{~min}$ of incubation at $37^{\circ} \mathrm{C}$ cell viability was read at 404 
A
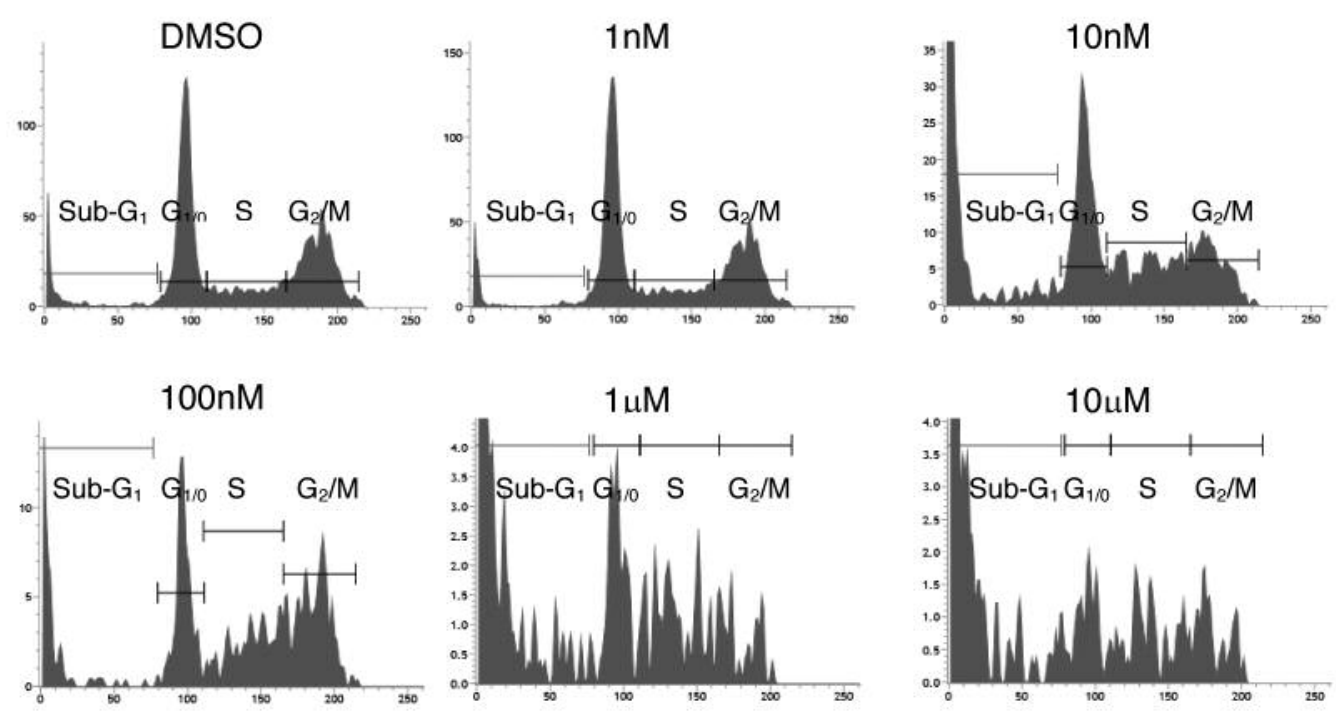

B

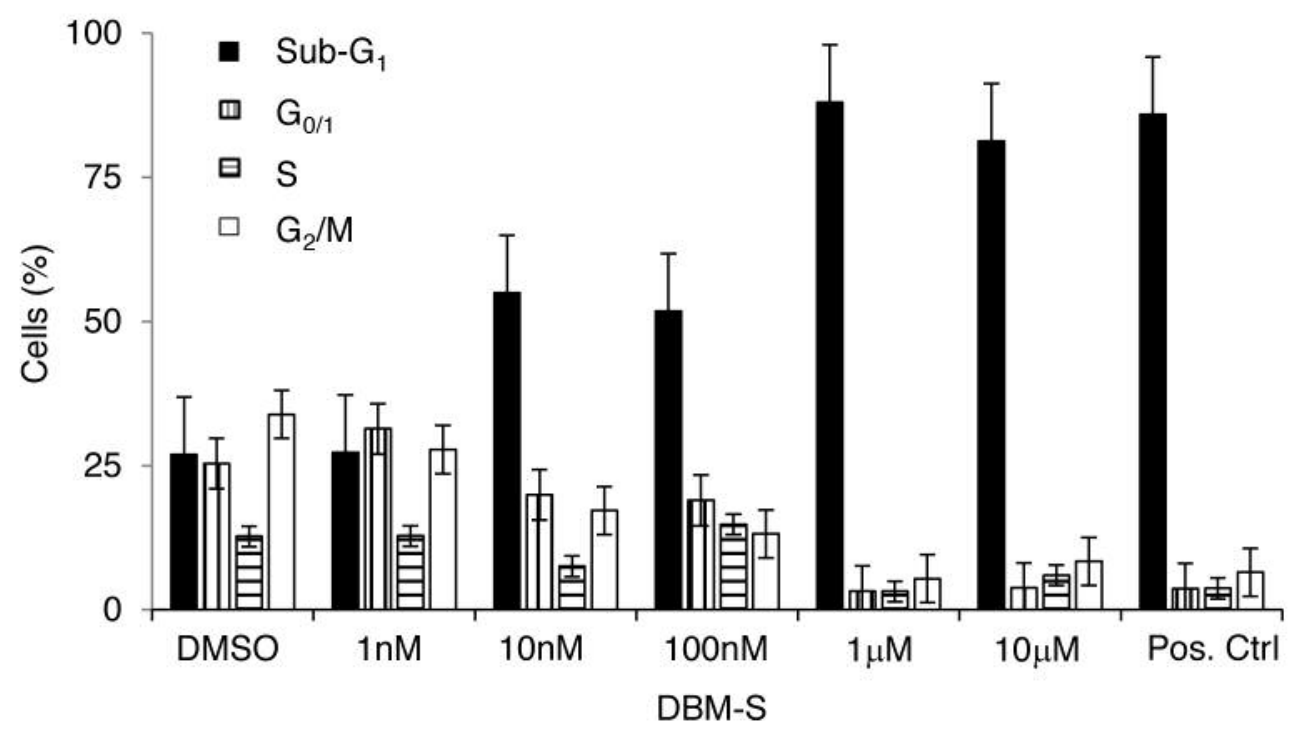

Figure 4. Saos 2 cells are sensitive to DBM-S treatment. A: Cell-cycle analysis of Saos 2 cells after 48 h of treatment with DBM-S showed a significant increase in sub-G $G_{l}$ cells with a concomitant increase in $G_{2}$-M-phase cells. B: Quantification of data shown in (A), indicating a significant increase in sub-G $G_{1}$ cells with increasing concentration of DBM-S. DMSO: Dimethyl sulfoxide (negative control) and Chlorpromazine (positive control).

excitation/520 emission with LUMIistar Omega multi-mode plate reader. Caspase assay was performed by adding part 2 of the ApotoxGlo $^{\circledR}$ as $100 \mu \mathrm{l} /$ well and incubating for $30 \mathrm{~min}$ at room temperature. The luminescence was read using the same plate reader in luminescence mode. The data were analysed and normalised to those of the vehicle control (DMSO). Data were collected as duplicates and statistical analysis calculated as SD using Microsoft Excel.

Cell-cycle analysis. Cell-cycle analysis was performed using a modified protocol described by Larson et al. (22). Briefly, Saos2 cells were treated with DMSO or 2',4'-dihydroxydithiondi- benzoylmethane for $48 \mathrm{~h}$, and thereafter cells were treated with Trypsin/EDTA for $10 \mathrm{~min}$ at $37^{\circ} \mathrm{C}$. Re-suspended cells were fixed with $500 \mu$ formaldehyde ( $4 \%$ formaldehyde in PBS) and incubated at $4^{\circ} \mathrm{C}$ for $20 \mathrm{~min}$. Cells were centrifuged at $400 \times g$ for $10 \mathrm{~min}$ and the pellet was washed in $1 \mathrm{ml}$ PBS. The pellet of cells was resuspended in $50 \mu \mathrm{l}$ RNAase solution and incubated at room temperature for $30 \mathrm{~min}$. The cells were washed again by adding PBS and centrifuged. DNA was stained with $50 \mu \mathrm{l}$ propidium iodide (50 $\mu \mathrm{g} / \mathrm{ml}$, Sigma Aldrich). The samples were then incubated at room temperature for $15 \mathrm{~min}$ in the dark and analysed by FACSVerse, BD Biosciences, San Jose, CA, USA. The results were 


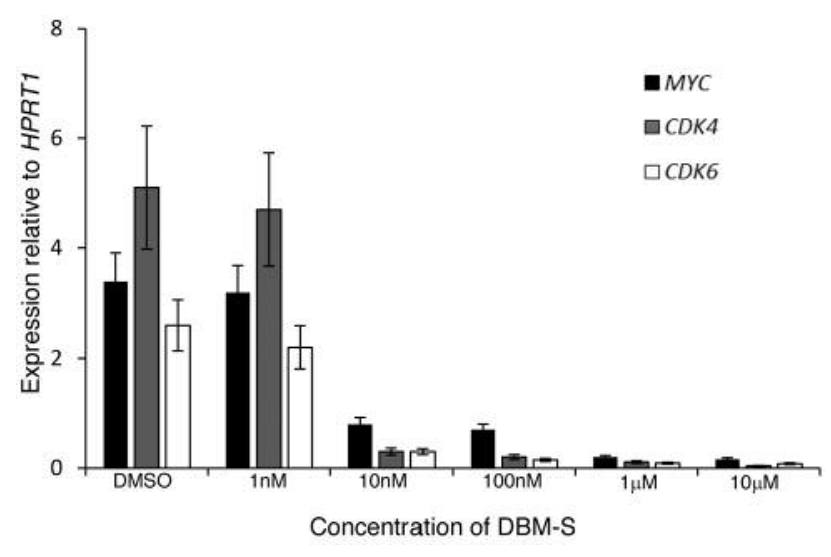

Figure 5. Cyclin-dependent kinase (CDK) 4 and 6 mRNA expression was significantly reduced by treatment with DBM-S. Quantitative analysis of Saos 2 cells after $48 \mathrm{~h}$ treatment with DBM-S showed decreased levels of MYC and concomitant drop in mRNA expression of CDK4 and CDK6 (p-value $<0.05$ at 100nM). HPRT1 was used as internal control.

analysed using BD FACSuite software (BD Biosciences). Data were collected as duplicates and statistical analysis calculated as SD using Microsoft Excel.

Quantitative RT PCR. RNA was extracted from Saos2 cells using the RNAeasy mini kit (Qiagen, Manchester, UK) as per manufacturer's instructions. Total RNA was used to generate first-strand complementary DNA by the following reaction: $2 \mu \mathrm{g}$ of total RNA, $4 \mu \mathrm{l} \mathrm{MgCl}{ }_{2}$ ( $25 \mathrm{mM}$ stock), $2 \mu \mathrm{l}$ of $10 \times$ First-Strand buffer, $2 \mu \mathrm{l}$ of dNTP Mix (10 mM stock), $1 \mu$ l of Random Hexamers $(500 \mathrm{mg} / \mathrm{ml}$ stock), $0.2 \mu$ RNAse OUT and $0.2 \mu$ of SuperScriptiII reaction volume was made up to a total of $20 \mu \mathrm{l}$ with deionised water. This mixture was first incubated for $10 \mathrm{~min}$ at $65^{\circ} \mathrm{C}$ and subsequently at $45^{\circ} \mathrm{C}$ for $1 \mathrm{~h}$. The reaction was then stopped by increasing the temperature to $85^{\circ} \mathrm{C}$ for $15 \mathrm{~min}$. Quantitative RT-PCR was performed on cDNA using AP BioSystems 7500 Thermal cycler using Syber Green (Thermo Fisher Scientific, Altrincham, Manchester, UK) relative quantitative method described earlier (23). The following primer sets were used for quantification: HPRT gene was served as internal control (F-GAGGAGTCCTGTTGATGT TGCCAG and RGGCTGGCCTATAGGCTCATAGTGC), CDK4 (F-ATGGCTACCTC TCGATATGAGC and R-CATTGGGGACTCT CACACTCT), CDK6 (F-GCTGACCAGCAGTACGAATG and R-GCACACATCAAAC AACCTGACC). Data were collected as duplicates and statistical analysis calculated as SD using Microsoft Excel.

\section{Results and Discussion}

Chemical synthesis. A new family of dibenzoyl-methane derivatives were synthesised as a one-pot reaction, in which an acylated phenol ester is formed from the reaction of a substituted acetophenone with benzyl chloride to yield a phenol ester, which then underwent a base-induced BakerVenkatarman rearrangement to yield the wanted aromatic1,3diketone. The thionylation of the 1,3-diketone of 2',4'- dihydroxy-dithiodibenzoyl-methane was performed using Lawesson's reagent. The compounds were purified using flash chromatography and then fully characterised (accurate MS, NMR and IR). The two carbonyl oxygens on the dibenzoylmethane derivatives are known to undergo hydrogen bonding; this was observed in the proton NMR at higher than $10 \mathrm{ppm}$. All starting materials are very economic hence the compounds were produced at a reduced cost, which is important when producing larger quantities for therapeutic purposes.

Biological activity. Saos2 (osteogenic sarcoma) is a bone cancer cell line derived from the primary osteosarcoma of an 11-yearold Caucasian girl. This cancer cell line possesses several osteoblastic features that make it extremely useful as a permanent line of human osteoblast-like cells for drug discovery and as a source of bone-related molecules (24). We tested all five compounds on HepG2 (childhood liver cancer), HCT116 (adult colonic cancer), A549 (adult lung cancer) (and Saos2 (childhood osteoclast) cell line for $72 \mathrm{~h}$ (Table I). 2',4'Dihydroxy-benzoyl-methane and 2',4'-dihydroxy-3'"-methoxybenzoyl-methane had similar activity against all the cell lines at $\mathrm{IC}_{50}$ of 4-10 $\mu \mathrm{M}$ for at $72 \mathrm{~h}$ of incubation. The amino substituent in 2'-hydroxyl-4'amino-benzoyl-methane produced loss of activity by a factor of 5 against HepG2, HCT116 and A549 cells with an $\mathrm{IC}_{50}$ approaching $20 \mu \mathrm{M}$. However, this compound showed a clear preference for toxicity towards Saos2 cells. From this group with hydroxyl and methoxy substitutions, 2',4'-dihydroxy-4"'-methoxy-benzoyl-methane presented high activity, with an $\mathrm{IC}_{50}$ at around $4 \mu \mathrm{M}$, but exhibited no selectivity for the cell lines. From our five compounds, the thionylated 1-(2',4'-dihydroxyphenyl)-3-phenylpropane1,3dithion had poor activity against HepG2 and A549 cells ( IC $_{50}$ of 33.43 and $43.54 \mu \mathrm{M}$ respectively), moderate activity against HCT116 cells ( $\mathrm{IC}_{50}$ of $\left.13.1743 .54 \mu \mathrm{M}\right)$ and a strong selective activity against Saos 2 cells $\left(\mathrm{IC}_{50}\right.$ of $\left.4.33 \mu \mathrm{M}\right)$. We observed this compound was between 3 - and 10- times more selective for the Saos 2 childhood osteoclast cell line. Chlorpromazeine acted as positive control, presenting $\mathrm{IC}_{50}$ values in the range of 5-11 $\mu \mathrm{M}$.

Apoptosis is a form of programmed cell death and is caspase-dependent, which is a safeguard mechanism protecting the organism while sacrificing the individual cell. Some drugs, such as doxorubicin and dactinomycin, are activators of the caspase pathway; caspase activation can appear in the very early stages, and sometimes this can be mistaken for necrosis (25). However, other pathways of cell death are also possible in which caspases are not activated. These can include: autophagy, paraptosis, mitotic catastrophe, and the descriptive model of apoptosis-like and necrosis $(26,27)$. Drugs with cytotoxic properties can trigger necrosis as death stimulus, with features such as disrupted cell membrane, destruction of organelles, swelling and then shrinking of the cell, and with the toxic waste being dispersed within the surrounding cells $(28,29)$. These 
Table I. Concentration of derivatives at which $50 \%$ of cell growth was inhibited (IC 50 ) against HepG2, HCT116, A549 and Saos2 human cancer cells after 72-h incubation.

\begin{tabular}{|c|c|c|c|c|}
\hline \multirow[t]{2}{*}{ Compound } & \multicolumn{4}{|c|}{$\mathrm{IC}_{50}(\mu \mathrm{M})$} \\
\hline & HepG2 & HCT116 & A549 & Saos2 \\
\hline 2', 4'-Dihydroxy-dibenzoyl-methane (1) & $4.9 \pm 1.2$ & $5.3 \pm 0.7$ & $4.7 \pm 0.9$ & $6.5 \pm 0.8$ \\
\hline 2'-Hydroxy-4'amino-dibenzoyl-methane (2) & $19.7 \pm 0.8$ & $13.9 \pm 2.9$ & $18.3 \pm 3.0$ & $5.4 \pm 1.2$ \\
\hline $\begin{array}{l}\text { 2',4-'Dihydroxy3"methoxy-dibenzoyl- } \\
\text { methane (3) }\end{array}$ & $9.3 \pm 1.3$ & $5.5 \pm 0.6$ & $6.6 \pm 0.6$ & $3.9 \pm 0.5$ \\
\hline $\begin{array}{l}\text { 2',4'-Dihydroxy4"methoxy-dibenzoyl } \\
\text { methane (4) }\end{array}$ & $3.9 \pm 1.0$ & $2.8 \pm 0.9$ & $2.8 \pm 0.5$ & $3.6 \pm 0.3$ \\
\hline $\begin{array}{l}\text { 1(-2',4'-Dihydroxy-phenyl)-3- } \\
\text { phenylpropane-1,3-dithion (5) }\end{array}$ & $33.4 \pm 2.9$ & $13.2 \pm 0.7$ & $43.5 \pm 3.1$ & $4.3 \pm 0.6$ \\
\hline $\begin{array}{l}\text { Chlorpromazine hydrochloride, positive } \\
\text { control }\end{array}$ & $7.6 \pm 0.7$ & $7.9 \pm 1.1$ & $10.9 \pm 1.5$ & $5.1 \pm 0.7$ \\
\hline
\end{tabular}

caspase-independent mechanisms can be produced by reactive oxygen species produced by external stimuli in the mitochondria (30). This mechanism can be activated by molecules interacting with the T-cell/interferon/Toll-like/TNF superfamily receptors (31) and various anticancer molecules such as ionomycin (32) and catechins from green tea, (33).

In a bid to identify a mode of action of our molecules, we employed the ApoToxGlo ${ }^{\circledR}$ (Promega) assay for assessing the mode of action. The caspase assay is composed of a substrate (proluminescent caspase-3/7 DEVD-aminoluciferin) which is cleaved and the free aminoluciferin is reacted by the luciferase, producing a luminescent signal proportional to the caspase-3/7 activity (34). We tested DBM-S at 5, 10 and $20 \mu \mathrm{M}$ for 24, 48 and $72 \mathrm{~h}$ and normalised the data to those of the vehicle control DMSO. The results indicate DBM-S reduced caspase activity steadily as the concentration used increased (Table II). At an exposure of $24 \mathrm{~h}$, the caspase activity was reduced by between $30-40 \%$, at 48 hours it was reduced to around $50 \%$ and for a longer exposure of $72 \mathrm{~h}$ the activity was similar to that of the 1-day exposure as the level of activity was around $60 \%$.
Cell division is regulated in an elaborate fashion to coordinate cell growth with DNA replication. The cell cycle is a series of events in which the cells synthesise DNA, proteins and all the materials needed to produce two daughters. This vital process is subdivided in four distinct phases, gap $1\left(\mathrm{G}_{1}\right)$, synthesis $(\mathrm{S})$, gap $2\left(\mathrm{G}_{2}\right)$ and mitosis $(\mathrm{M})$, each of which is under strict control of protein called cyclins and cyclindependant kinases (CDK). Complexes of cyclins with CDKs trigger the progression of the cell cycle, where cyclins act as regulatory subunits and the CDKs are the catalytic subunits. When both are activated and bound, through phosphorylation, this coordinates the cell's next step (35). Selectively blocking cell-cycle progression is an effective treatment for many types of cancer by arresting their development $(36,37)$.

We studied the cell-cycle progression of the Saos 2 cell line in the presence and absence of DBM-S. Cell-cycle analysis showed that within $48 \mathrm{~h}$ of treatment, proliferation of Saos2 cells was significantly reduced, with a concomitant increase in subG $_{1}$-phase cells, indicating significant apoptosis (Figure 4). Treatment with DBM-S induced cell-cycle arrest indicating 
Table II. Relative caspase activity in Saos2 cells after treatment with 2',4'-dihydroxy-dithiodibenzoyl-methane (DBM-S) for different periods.

\begin{tabular}{llll}
\hline DBM-S $(\mu \mathrm{M})$ & \multicolumn{3}{c}{$\begin{array}{c}\text { Relative caspase activity, } \\
\text { normalised to DMSO-treated cells }\end{array}$} \\
\cline { 2 - 4 } & 24 Hours & 48 Hours & 72 hours \\
\hline 5 & $77.2 \pm 0.3$ & $49.8 \pm 2.9$ & $66.6 \pm 30.8$ \\
10 & $69.1 \pm 4.3$ & $48.3 \pm 5.4$ & $61.3 \pm 6.9$ \\
20 & $59.2 \pm 15.1$ & $40.5 \pm 11.2$ & $53.4 \pm 0.7$ \\
\hline
\end{tabular}

DMSO: Dimethyl sulfoxide.

disruption of the cell-cycle control mechanism. To evaluate this further, we analyzed the relative mRNA expression levels of $C D K 4$ and $C D K 6$ along with transcription factor $M Y C$ that controls the expression of cyclins with internal housekeeping control gene using HPRT1 (Figure 5). Expression of the protooncogene cMYC is known to be correlated with cell-cycle progression, with it being very low in non-proliferating cells and highly expressed when cells are to progress to $\mathrm{S}$ phase from $\mathrm{G}_{1}(38,39)$. In addition, $M Y C$ is known to directly activate transcription of CDKs and hence plays a major role in cancer progression (40-41). Quantitative PCR results indicated that $M Y C$ mRNA levels were greatly reduced within $48 \mathrm{~h}$ of drug treatment. Moreover, CDK4 and CDK6 mRNA expression levels were also significantly reduced. This shows this novel compound arrested the cells, stopping them from dividing. Such reduction in mRNA levels might be a direct effect of drug treatment or the consequence of apoptosis triggered by DBM-S.

\section{Conclusion}

Treating cancer in children aggressively is the best option for continued health, despite the risk that side-effects can arise years later. Sometimes sequelae from surgery can also diminish subsequent quality of life. Producing new selective and effective anticancer agents has become a goal for many laboratories which are now focusing their resources in this direction to achieve that aim. Here we used classic organic reactions to produce a family of dibenzoyl-methane derivatives with promising anticancer activities. Using established organic methods, we very cheaply produced five compounds that were tested for anticancer activity on different cell lines including hepatic, colon, lung and osteoblast cancer. Although all compounds showed some degree of activity against the cancer cell lines, DBM-S produced the most promising and interesting results. This novel compound, tested on different types of cancer cells, was shown to be very selective for osteoblasts, which could lead to the deduction that this compound would produce fewer gastrointestinal side-effects; this property can be exploited in formulation studies. It is possible that primary necrosis is the mechanism inducing cell death of Saos2 cells, however, sub- $\mathrm{G}_{1}$ cell accumulation indicates DNAse activation, which is considered a feature of apoptosis and this could be a very early stage in a multi-pathway activity. $G_{1}$ arrest of Saos 2 cells also indicates a block in cell-cycle progression consistent with inhibition of CDKs as a mechanism of action. Although more work will follow, this novel thionylated compound based on dibenzoyl-methane opens the possibility of studies for combination therapy in order to achieve less toxic side-effects during the treatment of bone cancer.

\section{Acknowledgements}

This research was funded by the University of Salford as part of the MSc research projects and the Manchester Metropolitan University research budgets. We would like to express our gratitude to: $\mathrm{Dr}$ Nanda Puspita, Ms, Basma A-1-Sudani, Mr Omar Elaskani and Ms Nasrin Ahmed for their help in the tissue culture at the University of Salford.

\section{References}

1 ACCO: Cancer in Children. Available from: http://www.acco.org/ blog/cancer-in-children/ [last accessed May 10, 2016].

2 CRUK: About cancer types. Available from: http:// www. cancerresearchuk.org/about-cancer/type/ [last accessed May 10, 2016].

3 Cancer.org: Bonce cancer key statistics. Available from: http://www.cancer.org/cancer/bonecancer/detailedguide/bonecancer-key-statistics [last accessed May 10, 2016].

4 Plantaz D, Tabone MD, Berger C, Poirée M, Ducassou S and Michel G: Long term follow-up after childhood cancer. Rev Pract 649(9): 1284-1289, 2014.

5 CRUK: The stages of bone cancer. Available from: http:// www.cancerresearchuk.org/about-cancer/ty pe/bone-cancer/ treatment/the-stages-of-bone-cancer [last accessed May 10, 2016].

6 BCRTOrgUK: Teenage bone cancer. Available from: http://www.bcrt.org.uk/tbc_teenage_bone_cancer.php [last accessed May 10, 2016].

7 Escalas C, Bourdet C, Fayech C and Demoor-Goldscmidt C: Long-term effects of radiation on the spine - Results of a cohort of symptomatic survivors of childhood and review of the literature. Bull Cancer 102(7-8): 684-690, 2015.

8 Sarcoma UK: Understanding Sarcoma. Available from: http://sarcoma.org.uk/about-sarcoma/understanding-sarcoma-0 [last accessed May 10, 2016].

9 Yoon JH, Kwon MM, Park HJ, SYPark, Lim KY, Joo K and Park BK: A study of docetaxel and irinotecan in children and young adults with recurrent or refractory Ewing sarcoma family of tumors. BMC Cancer 14(1): 622, 2014.

10 Shalaby MS, Walker G, O'Toole S, Hammond P and Carachi R: The long-term outcome of patients diagnosed with sacrococcygeal teratoma in childhood. A study of a national cohort. Arch Dis Child 99(11): 1009-1013, 2014.

11 CRUK: Bone cancer treatment. Available from: http://www. cancerresearchuk.org/about-cancer/type/bone-cancer/treatment/ [last accessed May 10, 2016]. 
12 NHS: Cancer of the bones. Available from: http://www.nhs.uk/ Conditions/Cancer-of-the-bone/Pages/Introduction.aspx [last accessed May 10, 2016].

13 Cancer.Org: Bone cancer. Available from: http://www.cancer.org/ cancer/bonecancer/index [last accessed May 10, 2016].

14 Ferrari S, Meazza C, Palmerini E, Tamburini A, Fagioli F, Cozza R, Ferraresi V, Bisogno G, Mascarin M, Cefalo G, Manfrini M, Capanna R, Biagini R, Donati D and Picci P: Nonmetastatic osteosarcoma of the extremity. Neoadjuvant chemotherapy with methotrexate, cisplatin, doxorubicin and ifosfamide. An Italian Sarcoma Group study (ISG/OS-Oss). Tumori 100(6): 612-619, 2014.

15 van Maldegem AM, Benson C, Rutkowski P, Blay JY, van den Berg H, Placzke J, Rasper M, Judson I, Juergens H, Dirksen U and Gelderblom $\mathrm{H}$ : Etoposide and carbo-or cisplatin combination therapy in refractory or relapsed Ewing sarcoma: a large retrospective study. Pediatr Blood Cancer 62(1): 40-44, 2015.

16 Le Deley MC, Paulussen M, Lewis I, Brennan B, Ranft A, Whelan J, Le Teuff G, Michon J, Ladenstein R, Marec-Bérard P, van den Berg H, Hjorth L, Wheatley K, Judson I, Juergens H, Craft A, Oberlin O and Dirksen U: Cyclophosphamide compared with ifosfamide in consolidation treatment of standard-risk Ewing sarcoma: results of the randomized non-inferiority EuroEWING99-R1 trial., J Clin Oncol 32(23): 2440-2448, 2014.

17 Sukumari-Ramesh S, Bentley JN, Laird MD, Singh N, Vender JR and Dhandapani KM: Dietary phytochemicals induce p53and caspase-independent cell death in human neuroblastoma cells. Int J Dev Neurosci 29(7): 701-710, 2011.

18 Kim N, Kim HM, Lee ES, Lee JO, Lee HJ, Lee SK, Moon JW, Kim JH, Kim JK, Kim SJ, Park SH, Chung CH and Kim HS: Dibenzoylmethane Exerts Metabolic Activity through Regulation of AMP-Activated Protein Kinase (AMPK)-Mediated Glucose Uptake and Adipogenesis Pathways. PLoS One 10(3): e0120104, 2015.

19 Jackson KM, DeLeon M, Verret CR and Harris WB: Dibenzoylmethane induces cell cycle deregulation in human prostate cancer cells. Cancer Lett 178(2): 161-165, 2002.

20 Huang MT, Lou YR, Xie JG, Ma W, Lu YP, Yen P, Zhu BT, Newmark $\mathrm{H}$ and Ho CT: Effect of dietary curcumin and dibenzoylmethane on formation of 7,12-dimethylbenz[a] anthracene-induced mammary tumors and lymphomas/leukemias in Sencar mice. Carcinogenesis 19(9): 1697-1700, 1998.

21 Ragazzon PA, Bradshaw T, Matthews C, Iley JN and Missailidis $\mathrm{S}$ : The characterisation of flavone-DNA isoform interactions as a basis for anticancer drug development. Anticancer Res 29(6): 2273-2283, 2009.

22 Larsen JK, Munch-Petersen B, Christiansen J and Jo̊gensen K: Flow cytometric discrimination of mitotic cells: resolution of $\mathrm{M}$, as well as G1, S, and G2 phase nuclei with mithramycin, propidium iodide, and ethidium bromide after fixation with formaldehyde. Cytometry 7(1): 54-63, 1986.

23 Aziz A, Soucie E, Sarrazin S and Sieweke MH: MafB/c-Maf deficiency enables self-renewal of differentiated functional macrophages. Science 326(5954): 867-871, 2009.

24 Rodan SB, Imai Y, Thiede MA, Wesolowski G, Thompson D, Bar-Shavit Z, Shull S, Mann K and Rodan GA: Characterization of a human osteosarcoma cell line (Saos-2) with osteoblastic properties. Cancer Res 47(18): 4961-4966, 1987.

25 Tao Z, Goodisman J, Penefsky HS and Souid AK: Caspase Activation by Anticancer Drugs: The Caspase Storm. Mol Pharmaceutics 4(4): 583-595, 2007.
26 Braker LE, Kruyt FA and Giaccone G: Cell Death Independent of Caspases: A Review. Clin Cancer Res 11(9): 3155-3162, 2005.

27 Kogel D and Prehn JHM: Caspase-Independent Cell Death Mechanisms. In: Madame Curie Bioscience Database In: Madame Curie Bioscience Database [Internet]. Austin (TX): Landes Bioscience; 2000-2013. Available from: http:// www. ncbi.nlm.nih.gov/books/NBK6197/ (Accessed February 2016)

28 Hassan M, Watari H, AbuAlmaaty A, Ohba Y and Sakuragi N: Apoptosis and Molecular Targeting Therapy in Cancer. Biomed Res Int 2014: 1-23, 2014.

29 Guicciardi ME, Malhi H, Mott JL and Gores GJ: Apoptosis and necrosis in the liver. Compr Physiol 3(2): 977-1010, 2013.

30 Jain MV, Paczulla AM, Klonisch T, Dimgba FN, Rao SB, Robering K, Schweizer F, Lengerke C, Davoodpour P, Palicharlaand VR, Maddika $\mathrm{S}$ and $\operatorname{Łos} \mathrm{M}$ : Interconnections between apoptotic, autophagic and necrotic pathways: implications for cancer therapy development. J Cell Mol Med 17(1): 12-29, 2013.

$31 \mathrm{Su}$ Z, YangZ, Xu Y, Chen Y and Yu Q: Apoptosis, autophagy, necroptosis, and cancer metastasis. Mol Cancer 14(1): 48, 2015.

32 Gupta A, Sharma VK, Vohra H and Ganguly NK: Inhibition of apoptosis by ionomycin and zinc in peripheral blood mononuclear cells (PBMC) of leprosy patients. Clin Exp Immunol 117(1): 56-92, 1999.

33 Iwasaki R, Ito K, Ishida T, Hamanoue M, Adachi S, Watanahe $\mathrm{T}$ and Sato Y: Catechin, green tea component, causes caspaseindependent necrosis-like cell death in chronic myelogenous leukemia. Cancer Science 100(2): 346-356, 2008.

34 Promega.com: Apotox-Glo manual. Available from: http://www.promega.com/ /media/Files/Resources/Protocols/Tec hnical\%20Manuals/101/ApoTox-Glo\%20Triplex\%20Assay\% 20Protocol.pdf [last accessed May 10, 2016].

35 Tait SW and Green DR: Caspase-independent cell death: leaving the set without the final cut. Oncogene 27(50): 6452-6461, 2008.

36 Nigg EA: Cyclin-dependent protein kinases: Key regulators of the eukaryotic cell cycle. BioEssays 17(6): 471-480, 1995.

37 Champeris Tsanirasa S, Kanellakisa N, Symeonidou IE, Nikolopoulou P, Lygerou Z and Taraviras S: Licensing of DNA replication, cancer, pluripotency and differentiation: An interlinked world?. Semin in Cell Dev Biol 30: 174-180, 2014.

38 Eisenberg E and Levanon EY: Human housekeeping genes are compact. Trends Genet 197: 362-365, 2003.

39 Sculley DG, Dawson PA, Emmerson BT and Gordon RB: A review of the molecular basis of hypoxanthine-guanine phosphoribosyltransferase (HPRT) deficiency. Hum Genet 903: 195-207, 1992.

40 Obaya AJ, Mateyak MK and Sedivy JM: Mysterious liaisons: the relationship between c-Myc and the cell cycle. Oncogene 18(19): 2934-2941, 1999.

41 Mateya MKk, Obaya AJ and Sedivy JM: c-Myc Regulates Cyclin D-Cdk4 and -Cdk6 Activity but Affects Cell Cycle Progression at Multiple Independent Points. Mol Cell Biol, 19(7): 4672-4683, 1999. 